\title{
Immunology of the Lower Respiratory Tract
}

\author{
FUNCTIONAL PROPERTIES OF BRONCHOALVEOLAR \\ LYMPHOCYTES OBTAINED FROM THE NORMAL \\ CANINE LUNG
}

\author{
H. B. Kaltremer and S. E. Salmon \\ From the Pulmonary Disease Group of the Department of Medicine and the \\ Cancer Research Institute, School of Medicine, University of California, \\ San Francisco, California 94143
}

A в S T R A C T While the alveolar macrophage has been studied extensively, little attention has been directed toward the immune functions of the bronchoalveolar lymphocyte. These cells, obtained by bronchopulmonary lavage of the normal canine lung, are derived from the air side of the alveolar-capillary membrane of the lower respiratory tract. The distribution of lymphocyte types within the bronchoalveolar cell population was determined and compared with that of leukocytes from blood and spleen.

$\operatorname{IgG}$ synthesis in vitro was used as a measure of bone marrow-derived lymphocyte (B cell) function, and the blastogenic response of cell cultures to phytohemagglutinin was used as a measure of the presence or absence of thymus-dependent lymphocytes ( $\mathrm{T}$ cells). $D e$ novo synthesis of $\mathrm{IgG}$ by bronchoalveolar cells was demonstrated consistently by two independent radioimmunoassays. Therefore, B cells are present in the air spaces of normal canine lungs. $T$ cells were generally not detectable in aliquots of the same cell populations but could be recruited into alveolar spaces after local irritation.

The distribution of lymphocyte types within the bronchoalveolar cell population is unique and distinctly

This work was presented in part at the National Meeting of the American Federation for Clinical Research, Atlantic City, N. J., May 1972.

Dr. Kaltreider is the recipient of a National Institutes of Health Special Fellowship (1 F03 HL-53181-01). Dr. Salmon's present address is the Section of Hematology and Oncology, Department of Medicine, University of Arizona College of Medicine, Tusson, Ariz. 85742.

Received for publication 22 Jamuary 1973 and in revised form 19 March 1973. different from that of blood and spleen. The spleen is rich in both $\mathrm{T}$ cells and $\mathrm{B}$ cells, blood is rich in $\mathrm{T}$ cells but poor in $\mathrm{B}$ cells, whereas the lung lacks $\mathrm{T}$ cells and contains substantial numbers of immunoglobulinproducing $\mathrm{B}$ cells. The findings indicate that bronchoalveolar lymphocytes do not reflect simply the lymphoid composition of peripheral blood.

\section{INTRODUCTION}

The normal immune response provides protection against injury or infection caused by materials inhaled into the lower respiratory tract (1-3); conversely, hypersensitive immune mechanisms may contribute to the pathogenesis of pulmonary disease (4). Systematic investigation of the normal immunophysiology of the lower respiratory tract is a necessary first step in the understanding of both pulmonary host-resistance and the lung disease produced by immune mechanisms. Although the functional properties of alveolar macrophages have been studied extensively $(1,5)$, relatively little attention has been paid to the role of the bronchoalveolar lymphocyte in local immune defenses (6-8).

Although composed predominantly of macrophages, the cell populations obtained by bronchopulmonary lavage $^{1}$ of several mammalian species, including man, contain morphologically identifiable lymphocytes (7, 9, 10). After antigenic stimulation of the respiratory tract, cells appear in alveolar spaces, and these have been reported to be capable of both specific antibody synthesis (11), a bone marrow-derived lymphocyte (B

\footnotetext{
${ }^{1}$ For convenience, these cell populations are termed "lung cells" in this report.
} 


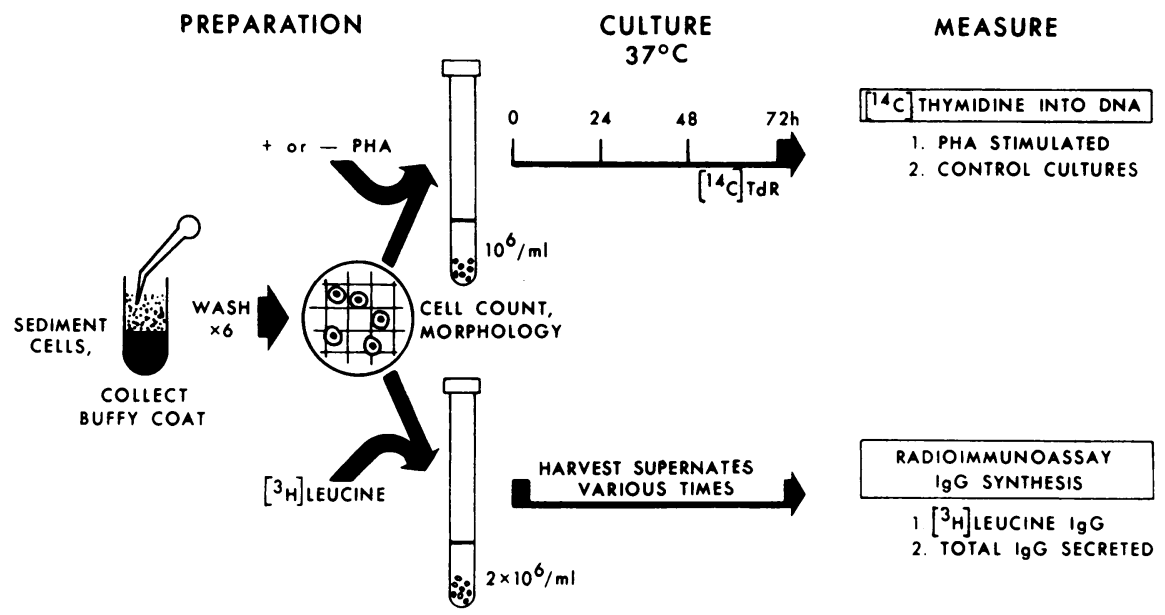

Figure 1 Diagrammatic representation of the standard experimental protocol used in these studies.

cell $)^{2}$ function, and cell-mediated immunity (6-8), a thymus-dependent lymphocyte ( $\mathrm{T}$ cell) function. The concept of a local pulmonary immune system (12) is supported by evidence that these immune responses occur in the lung after immunization by the respiratory, but not by the systemic, route $(7,8)$. While these data suggest that alveolar spaces contain immunocompetent cells after local antigenic stimulation, it is not clear whether immunocytes normally reside in the alveoli and peripheral airways, or whether they are recruited only in the presence of appropriate antigens.

We have studied the immune capabilities of lung cells obtained from the normal dog. Since this cell population contains no erythrocytes, we considered that it exists on the air side of the alveolar-capillary membrane and, as such, represents cells potentially available for interaction on initial exposure to airborne antigens. The dog was studied because it allowed us to obtain serially large samples of lung cells from living animals, and it provides the potential for future correlation of immunopathology with pulmonary physiology.

Our studies were specifically designed to answer the following questions: (a) Are immunocompetent cells normally present in the bronchoalveolar air spaces? (b) If so, does the cell population contain functional $\mathrm{T}$ cells and functional B cells? (c) What is the distribution of $T$ cells and $B$ cells in the lung-cell population relative to that found in blood and in spleen?

For purposes of this study, we defined lymphocytes on the basis of functional rather than morphologic

${ }^{2}$ Abbreviations used in this paper: B cells, bone marrowderived lymphocytes; BGG, bovine immunoglobulin G; HBSS, Hanks' balanced salt solution; HIHS, heat-inactivated horse serum; PHA, phytohemagglutinin; $\mathrm{T}$ cells, thymus-dependent lymphocytes. criteria. We assumed that immunoglobulin synthetic capacity in vitro is a measure of B-cell function and the proliferative response to phytohemagglutinin ( $\mathrm{PHA}$ ) is a measure of $\mathrm{T}$-cell function. These assays were used to detect lymphocytes within the lung-cell population and to compare relative proportions of $B$ cells and $T$ cells among nucleated cell populations derived from lung, blood, and spleen.

\section{METHODS}

Animals. Normal adult mongrel dogs of either sex weighing $30-35 \mathrm{lb}$ were used. They were housed in the Animal Care Facility of this institution without special precautions. The animals were sacrificed after single-lavage experiments; those used for serial studies were housed in the facility between experiments.

Experimental design. Two types of experiments were performed: (a) experiments in which a single bronchopulmonary lavage was performed on an intact, healthy dog in order to explore the characteristics of normal lung cells, and $(b)$ experiments in which serial lavages were performed on the same animal at weekly intervals in order to assess the effect of repeated lavage or of instillation of irritants on the composition of the lung-cell population.

Collection of specimens. The dogs were lightly anesthetized with intravenous thiopental. Bronchopulmonary lavage was performed in the living animal through a double-lumen balloon catheter (13) placed in a bronchus of a lower lobe under fluoroscopic control. Each lower lobe was lavaged with a total of $250 \mathrm{ml}$ of Hanks' balanced salt solution (HBSS, Grand Island Biological Co., Berkeley, Calif.) containing $2 \mathrm{U}$ of heparin/ml (Lipo-Hepin, Riker Laboratories, Northridge, Calif.) and antibiotics (antibioticantimyocotic mixture, Grand Island Biological Co.). The yield was $15-20 \times 10^{8}$ nucleated cells per animal.

Blood leukocytes were obtained by venipuncture and splenic leukocytes by percutaneous aspiration. Specimens were drawn into syringes containing heparin.

Processing of cells. The standard protocol employed in these experiments is depicted diagrammatically in Fig. 1. 
The lung cells were collected by centrifugation at $250 \mathrm{~g}$ for $10 \mathrm{~min}$. Suspensions of blood and spleen cells were sedimented in the presence of $3 \%$ dextran (mol wt 70,000, McGaw Laboratories Inc., Glendale, Calif.) at room temperature for 30-60 min. The leukocyte-rich supernate was removed and the cells collected by centrifugation (250 $\mathrm{g}$ for $10 \mathrm{~min}$ ). In order to remove preformed immunoglobulin, all three cell populations were washed by centrifugation in six changes of HBSS containing $2 \mathrm{U}$ of heparin/ml, $10 \%$ heatinactivated horse serum (HIHS, Grand Island Biological Co.) and antibiotics. Giemsa-stained cytocentrifuge slide preparations were used for morphologic study.

Response to phytohemagglutinin. A portion of each cell population was assayed for its blastogenic response to PHA. Cultures were performed in at least triplicate, with and without PHA, in 2-ml samples at a concentration of $10^{\circ}$ nucleated cells $/ \mathrm{ml}$ at $37^{\circ} \mathrm{C}$ in air enriched with $5 \%$ $\mathrm{CO}_{2}$. Culture medium was McCoy's 5a (Grand Island Biological Co.) containing 20\% HIHS and antibiotics. Phytohemagglutinin (PHA-P, Difco Laboratories, Detroit, Mich.) was added to appropriate tubes at several concentrations $(34,6.8$, and $3.4 \mu \mathrm{g} / \mathrm{ml}$ ), and the results from the maximally stimulated cultures are reported here. Generally, the optimal concentration of PHA was $6.8 \mu \mathrm{g} / \mathrm{ml}$. After $48 \mathrm{~h}$ of incubation, $0.05 \mu \mathrm{Ci}$ of $\left[{ }^{14} \mathrm{C}\right]$ thymidine $/ \mathrm{ml}$ was added to each culture. $24 \mathrm{~h}$ later the cells were collected by centrifugation, washed twice in 5\% trichloroacetic acid and twice in absolute methanol. The precipitates were dissolved in $5 \mathrm{ml}$ of Aquasol (New England Nuclear, Boston, Mass.), followed by $5 \mathrm{ml}$ of Liquifluor (New England Nuclear), and the radioactivity was determined in a Packard Tri-Carb liquid scintillation counter (model 3375, Packard Instrument Co., Inc., Downer Grove, Ill.). Results were expressed both as net counts per minute (the arithmetic difference between stimulated and control cultures) and as the ratio of stimulated to control counts per minute (stimulation index).

Synthesis of $I g G$. A specimen of washed cells from lung, blood, or spleen was adjusted to a concentration of $2 \times 10^{8}$ nucleated cells $/ \mathrm{ml}$ in tissue culture medium consisting of leucine-free minimal essential medium (Grand Island Biological Co.) containing L-glutamine $(4 \mathrm{mM})$, antibiotics, $20 \% \mathrm{HIHS}$, and $\mathrm{L}-\left[{ }^{3} \mathrm{H}\right]$ leucine $(2.0 \mu \mathrm{Ci} / \mathrm{ml})$. Suspension cultures were performed in samples of $2-3 \mathrm{ml}$ in Falcon plastic tubes (Falcon Plastics, Los Angeles, Calif.) at $37^{\circ} \mathrm{C}$ in air enriched with $5 \% \mathrm{CO}_{2}$ (fluid $\mathrm{pH}, 7.2$ ). Supernates were harvested by centrifugation at intervals of approximately $48 \mathrm{~h}$ from 0 to 8 days and stored frozen until assayed for IgG by radioimmunoassay.

Radioimmunoassay's. Two assay procedures were used to measure IgG in the cell supernates. The total IgG content was determined by a modification of the solid-phase "sandwich" inhibition radioimmunoassay (14). In order to study synthesis of canine IgG, purified canine IgG and monospecific rabbit antiserum to canine $\operatorname{IgG}$ were used in the assay system. Phosphate-buffered saline ( $\mathrm{pH}$ 7.3) containing $1 \%$ HIHS was used as the assay diluent. The standard curve for inhibition immunoassay was linear between 50 and $200 \mathrm{ng}$ of $\mathrm{IgG} / \mathrm{ml}$. Results are expressed as $\mathrm{ng}$ of $\mathrm{IgG} / 10^{6}$ nucleated cells.

Endogenously labeled IgG $\left({ }^{3} \mathrm{H}\right]$ leucine $)$ was detected in supernates by the immunologically specific binding of labeled immunoglobulin to plastic tubes coated with antiserum to canine IgG (direct binding assay) (15). The tubes were washed, dried, and dissolved in $15 \mathrm{ml}$ of scintillation fluid (Liquifluor); the radioactivity was determined by liquid scintillation counting. A duplicate set of assays was performed in the presence of $1.0 \mathrm{mg}$ of unlabeled canine $\operatorname{IgG}$ per $\mathrm{ml}$ of medium to block the binding of intrinsically labeled immunoglobulin in the samples. These served as a control for immunologic specificity. The counts specifically blocked were considered proportional to the magnitude of IgG synthesis. Results were expressed as blocked cpm $/ 10^{6}$ nucleated cells.

Local irritation of the loccer respiratory tract. Bovine IgG (BGG) was prepared from Cohn fraction II (Sigma Chemical Co., St. Louis, Mo.) by DEAE-cellulose chromatography. The protein, eluted with $0.02 \mathrm{M}$ of Tris- $\mathrm{HCl}$ buffer, $\mathrm{pH} 8.0$, was coupled to autologous canine erythrocytes with chromic chloride (16). Sheep erythrocytes were obtained from Mogul Diagnostics (Division of Mogul Corp., Madison, Wis.) and were washed with HBSS before use. Approximately $5 \mathrm{ml}$ (packed cell volume) of either BGGerythrocytes or sheep erythrocytes were instilled directly into the alveolar spaces through a double-lumen balloon catheter.

\section{RESULTS}

\section{Identification and functional characterization of lymphocytes from normal canine lungs}

Morphology. The cell population obtained from normal canine lungs was pleomorphic. Cells resembling macrophages of different sizes accounted for approximately $75 \%$ of the cells (range $68-80 \%$ ). Morphologically identifiable lymphocytes made up an average of $23 \%$ (range 18-32\%) of the population. Uncertainty exists with respect to intermediate-sized cells (accounting for approximately one-third of those cells classified as lymphocytes) that could not be definitely identified as either small macrophages or medium-sized lymphocytes. We were unable to resolve this uncertainty by tests of phagocytic function or by histochemical staining (lipase). Polymorphonuclear leukocytes were seen occasionally $(0-9 \%)$. Erythrocytes were rarely observed. Plasma cells were difficult to identify when first obtained, but they were easily found after $2-4$ days of culture.

Synthesis of IgG. Synthesis and release of IgG by the normal lung-cell population was demonstrated in seven of eight single-lavage experiments, performed on eight different animals, by both the standard inhibition and the direct binding radioimmunoassays (Fig. 2). There was a time-dependent net increase of IgG released into the culture supernates. The inhibition assay (Fig. 2A) shows the variability among animals both in rate of synthesis and in total IgG accumulated in the culture supernates $\left(75-425 \mathrm{ng} / 10^{\circ}\right.$ cells $)$. The direct binding assay of labeled IgG (Fig. 2B), which is an independent assay system, confirmed results of the inhibition assay with remarkable consistency, both qualitatively and quantitatively for each animal, and proved that the appearance of $\operatorname{IgG}$ in the supernate resulted from synthesis of IgG de novo rather than from simple release of preformed immunoglobulin from cells.

Response to $P H A$. The blastogenic response of lung cells to PHA was compared with that of peripheral 

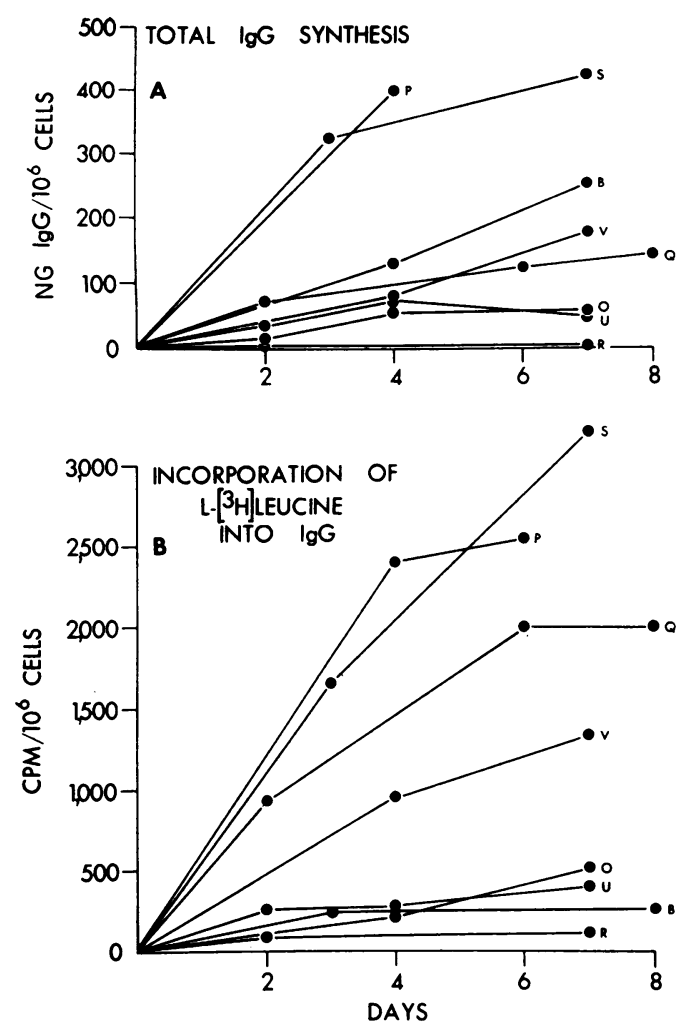

FIGLRE 2 Synthesis of IgG in vitro by lung cells obtained from single bronchopulmonary lavage of normal dogs. (A) Time-dependent accumulation of total $\operatorname{IgG}$ in culture supernates, measured by inhibition radioimmunoassay and expressed as $\mathrm{ng} / 10^{8}$ nucleated cells. (B) Incorporation of $\mathrm{L}-\left[{ }^{3} \mathrm{H}\right]$ leucine into IgG by simultaneously obtained samples from the same dogs, measured by the direct binding radioimmunoassay. The counts per minute represent those specifically blocked by an excess of unlabeled IgG; letters identify individual animals. The two assays are mutually confirmatory for each animal.

blood leukocytes in seven separate experiments (Fig. $3)$. As expected, blood leukocytes in the presence of PHA increased their incorporation of $\left[{ }^{14} \mathrm{C}\right]$ thymidine into DNA. By contrast, lung cells cultured under identical conditions failed to respond to PHA in five of seven experiments. Experiment $\mathrm{S}$ showed a significant response of lung cells, although the degree of stimulation was distinctly less than that of blood leukocytes. In experiment $\mathrm{V}$, the control lung culture had an unusually high number of counts $(300 \mathrm{cpm})$, a phenomenon that we have observed in the presence of inflammation of the lung. This lung-cell population contained $9 \%$ polymorphonuclear leukocytes (normal, less than $2 \%$ ).

Mixing of lung cells and blood leukocytes showed that the failure of lung cells to respond to PHA was not due to the presence of any inhibitor of blastogenesis. Dose-response curves performed on responsive lungcell populations and on blood leukocytes were identi- cal, indicating that PHA-responsive lung cells, when present, do not differ qualitatively in this regard from blood lymphocytes. Serial dilutions of blood leukocytes showed that our assay can detect responsive lymphocytes at a level somewhat less than $1 \%$ of the standard concentration of cells $\left(10^{8} / \mathrm{ml}\right)$.

We frequently observed a striking increase in uptake of labeled thymidine by control cultures after several pulmonary lavages. This phenomenon resulted in a low blastogenic index despite a marked increase in the net counts incorporated in the presence of PHA. Autoradiographs of these control cultures showed that nuclear labeling with $\left[{ }^{3} \mathrm{H}\right]$ thymidine occurred predominantly in cells having the appearance of young lymphocytes. These data suggested the recruitment of a PHA-responsive, spontaneously proliferating cell population into the bronchoalveolar spaces.

To demonstrate this recruitment of $\mathrm{T}$ cells, foreign particulate substances were administered directly into the lower respiratory tract. Both BGG-coated autologous erythrocytes and sheep erythrocytes produced a dramatic increase in PHA-responsive cells after each of several instillations (Table I). Thus, although functional $\mathrm{T}$ cells are normally undetectable among lung cells, these immunocytes may be recruited into air spaces by local irritation.

Relative proportions of $\mathrm{B}$ cells and T cells in lung-cell populations compared with those in blood and spleen

Distribution of $B$ cells and $T$ cells in lung-coll populations. After demonstrating consistently the presence

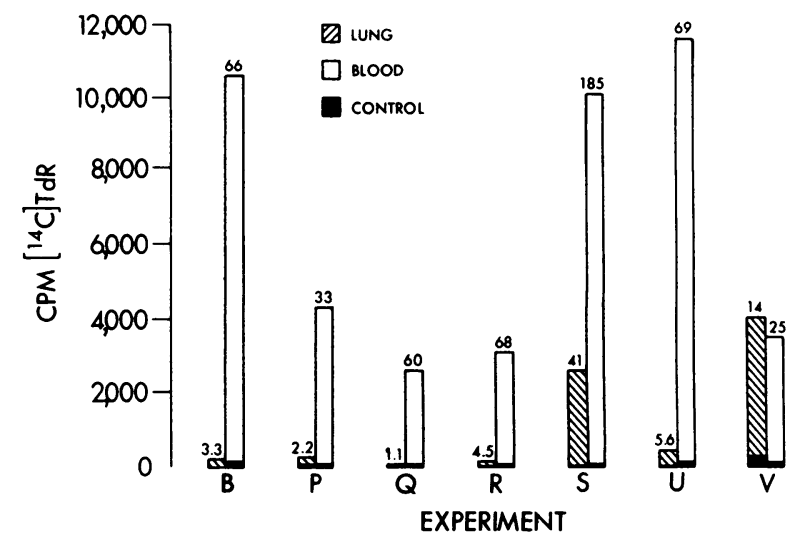

Figlke 3 Blastogenic response to PHA of lung cells (hatched bars) and of simultaneously obtained leukocytes from peripheral blood (open bars). Solid areas are control cultures. The number above each bar is the stimulation index; letters identify individual animals. The cultured cells were aliquots of those used in the IgG synthesis studies (Figs. 2A and B). Results, expressed in counts per minute, are incorporation of $\left[{ }^{14} \mathrm{C}\right]$ thymidine per culture (see Methods). 
TABLE I

Appearance of $T$ Cells in Air Spaces after Local Irritation

Blastogenic response to $\mathrm{PHA}$ (cpm of $\left[{ }^{14} \mathrm{C}\right]$ thymidine incorporated)

\begin{tabular}{lrrrrr} 
& \multicolumn{1}{c}{$\begin{array}{c}\text { Days } \\
\text { after } \\
\text { instil- } \\
\text { lation }\end{array}$} & Control & PHA & Net & Index \\
\hline Dog R: BGG-R BC & & & & & \\
Control & 0 & 32 & 147 & 115 & 4.5 \\
& 0 & 54 & 841 & 787 & 15.6 \\
Instillation 1 & 7 & 189 & 1,137 & 948 & 6.0 \\
& 18 & 108 & 2,076 & 1,968 & 19.2 \\
Instillation 2 & 29 & 195 & 11,913 & 11,718 & 68.0 \\
& 3 & 29 & 524 & 495 & 18.0 \\
Dog J4: Sheep RBC & 10 & 62 & 7,035 & 6,973 & 114.0 \\
Control & 17 & 47 & 2,681 & 2,634 & 57.0 \\
Instillation 1 & 0 & 60 & 133 & & \\
& 4 & 114 & 376 & 262 & 3.3 \\
Instillation 2 & 8 & 302 & 998 & 698 & 3.3 \\
& 4 & 102 & 403 & 301 & 4.0 \\
Instillation 3 & 9 & 106 & 1,223 & 1,117 & 12.0 \\
& 23 & 421 & 3,452 & 3,031 & 8.2 \\
& 7 & 601 & 2,417 & 1,816 & 4.0 \\
\hline
\end{tabular}

of immunoglobulin-producing cells and the occasional presence of $\mathrm{T}$ cells in normal canine lungs, we compared the distribution or proportion of these cell types with that in populations of leukocytes from blood and spleen (Fig. 4). Synthesis of IgG by lung and blood leukocytes was approximately equivalent, but considerably less than that of spleen. By contrast, the response to PHA of lung cells was markedly less than that of either blood or spleen.

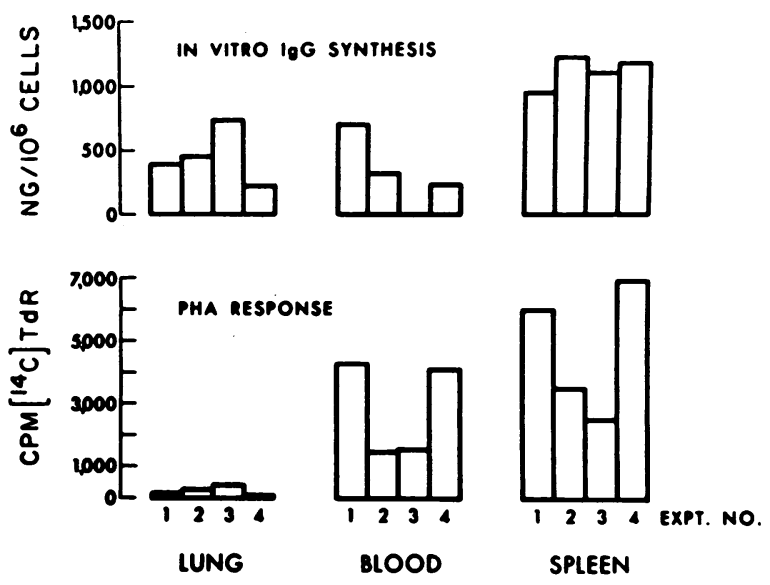

Figure 4 IgG synthesis and response to PHA stimulation of lung, blood, and spleen leukocytes in four weekly experiments on the same animal $(\operatorname{dog} P)$. Upper panel, maximal synthesis of IgG in each experiment (expressed as ng $\mathrm{IgG} / 10^{6}$ nucleated cells); lower panel, net counts per minute of $\left[{ }^{14} \mathrm{C}\right]$ thymidine incorporated in the presence of PHA.
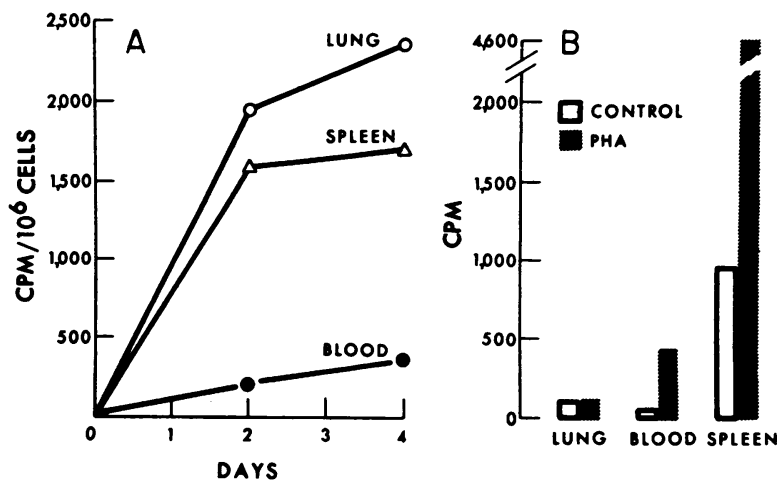

Figure 5 Comparison of IgG synthetic capacities of lung, blood, and spleen leukocytes (A) with blastogenic response to PHA of aliquots of the same cell populations (B). The differences in lymphocyte types among the three tissues are clear. Immunoglobulin synthesis was measured by the direct binding radioimmunoassay and response to $\mathrm{PHA}$ by the incorporation of $\left[{ }^{14} \mathrm{C}\right]$ thymidine into DNA.

The difference between $\mathrm{B}$-cell and $\mathrm{T}$-cell function in the lung is emphasized by the results of a single experiment on a different animal (dog D) (Fig. 5). Here, synthesis of IgG by lung cells was exceptionally great, actually exceeding that of spleen (Fig. 5A). It is significant, then, that a sample of this same population of lung cells showed no response to PHA (Fig. 5B) despite a brisk response by leukocytes from both blood and spleen.

As expected, the splenic leukocyte population is rich in both $\mathrm{B}$ cells and $\mathrm{T}$ cells, and the blood contains predominantly, but not exclusively, $\mathrm{T}$ cells. The lung-cell population, however, resembles neither and is distinctive in that it contains B cells almost exclusively.

\section{DISCUSSION}

In these studies we have attempted to define and characterize the lymphoid component of the heterogeneous cell population obtained from the normal canine lung by bronchopulmonary lavage. Morphologically identifiable lymphocytes accounted for approximately $23 \%$ of the lung-cell population. In order to circumvent morphological uncertainties we employed functional criteria to identify and categorize lymphoid cells. We made the assumption that $B$ cells and $T$ cells derived from various organ systems are functionally similar. We took the magnitude of our assay results as an estimate of the numbers of functional $\mathrm{B}$ cells and $\mathrm{T}$ cells present in each of the populations studied, regardless of morphology.

We have expressed our data relative to $10^{8}$ unfractionated leukocytes in order to compare the relative numbers of $B$ cells and $T$ cells present within each tissue. Since these populations were obtained simul- 
taneously and cultured under identical conditions, and since the assay systems for $B$ cells and $T$ cells are of the same order of sensitivity, the assay results may be taken as a direct estimate of the number of $B$ cells and $\mathrm{T}$ cells contained within each population. Expressed in this manner, comparisons among diverse cell populations are valid.

Synthesis of $\operatorname{IgG}$ in vitro by lung cells was consistently demonstrated by two independent radioimmunoassay techniques. The immunochemical specificity of the assays, the agreement between them. and the demonstration of IgG synthesis de noi'o leaves no doubt that $B$ cells are present in normal lung-cell populations. The time course of several days until peak IgG synthesis occurs suggests maturation of $\mathrm{B}$ cells in vitro toward immunoglobulin-producing plasma cells. These results clearly establish that the normal canine lung contains cells capable of immunoglobulin (antibody) synthesis and demonstrate that $B$ cells and/or their derivates (plasma cells) are normally present on the air side of the alveolar-capillary membrane.

Our data are relevant only to IgG. Secretory IgA is the predominant immunoglobulin in upper airway secretions in several species, including man (17): it functions to protect against certain viral respiratory infections (18). In the lower respiratory tract the relative contribution of the individual immunoglobulin classes to the immune response has not been elucidated, but recent evidence suggests that both $\operatorname{IgG}$ and $\mathrm{IgM}$ are important (19). Immunoglobulin $\mathrm{G}$ is present in micrograms per milliliter amounts in the lavage fluids we have studied, ${ }^{3}$ indicating that large quantities of IgG are normally present in bronchoalveolar air spaces. Efforts to determine the relative distribution of $\mathrm{IgG}$, $\operatorname{IgA}$, and $\operatorname{Ig} \mathrm{M}$ in lavage fluids and lung-cell culture supernates are currently in progress.

We were unable to detect significant numbers of cells responsive to $\mathrm{PHA}$ among populations derived from the normal lung. Since only $\mathrm{T}$ cells undergo blastogenesis in the presence of $\mathrm{PHA}$, these results indicate that very few of these cells are normally present in the lung. No inhibitors of the blastogenic response were found in the lung-cell preparations. It is possible that the difference in numbers of $B$ cells and $T$ cells detected among the lung-cell populations may, in part, be caused by a differential sensitivity of the assay procedures employed. However, we estimate from independent experiments that both assays are capable of detecting the presence of the appropriate cell type at a concentration approximately $1 \%$ of the cultured cell population. The occasional presence of $\mathrm{T}$ cells in normal lung cells, plus their ready identification in exudates stimulated by foreign

\footnotetext{
${ }^{3}$ Unpublished observations.
}

materials, suggests that these cells are not normally residents of the pulmonary air spaces, but that they are readily available and can be recruited by appropriate stimulation. The finding of a rapidly and spontaneously proliferating cell population that appears to respond to PHA after stimulation is of interest: however, these data do not tell us whether immature $T$ cells were recruited into air spaces or whether a small resident population of $\mathrm{T}$ cells was stimulated to divide.

The three leukocyte populations (blood, lung, and spleen) differed markedly in their relative concentrations of $\mathrm{B}$ cells and $\mathrm{T}$ cells. The spleen is rich in both types of immunocytes, while blood contains predominantly $T$ cells. Lung-cell populations contain B cells, and $T$ cells are not usually detectable. These data indicate that bronchoalveolar lymphocytes do not reflect simply the lymphoid composition of circulating peripheral blood.

Since B cells were consistently found in normal lungs, they appear to be normally present in the lower respiratory tract. The anatomic origin of these cells may be the lamina propria of peripheral airways where localized collections of plasma cells and lymphocytes are known to exist (20), or they may be derived from the circulating lymphocyte pool. Our inability to detect $T$ cells in air spaces suggest that few, if any, of these cells are static inhabitants of the normal lower respiratory tract. The thymus-dependent lymphocyte is known to continually circulate through blood, tissue, and lymph seeking the antigen to which it has been precommitted (21). If the same process occurs in the lung, large accumulations of $\mathrm{T}$ cells in air spaces would be expected only in the presence of antigen.

From these considerations and from our data, the general functional characteristics of an immune system in the lower respiratory tract begin to emerge. It is important to recognize that the cells we are discussing have been derived from the lower respiratory tract (small bronchi, bronchioles, and alveoli), and that these cells may be distinctly different from those of the nasopharynx and large airways. Additionally, these immunocytes have been derived from the air side of the pulmonary capillary wall. Within the confines of these anatomic boundaries, we have defined a distinctive and unique population of lymphocytes which exists under normal physiologic conditions. We postulate that this system could provide for the immediate availability of $B$ cells to mount a rapid humoral (antibody) immune response to the initial exposure to airborne antigen, and that $T$ cells have access to air spaces to perform cellmediated immune functions. While our data are consistent with this concept of a local immune system in the lung, further studies will be required to determine whether bronchoalveolar lymphocytes respond to anti- 
genic stimulation in situ or whether participation by the central immune apparatus is required.

\section{ACKNOWLEDGMENTS}

The authors thank Ms. Beth A. Smith and Ms. Luana Kyselka for skilled technical assistance, Dr. Martin J. Cline for helpful suggestions, and Dr. John F. Murray for encouragement and support.

This work was supported in part by grant CA-11067 from the U. S. Public Health Service and aided by grants from the California Research and Medical Education Fund of the California Lung Association, and the School of Medicine Committee on Research Evaluation and Allocation (Ackerman Fund). Part of this work was performed while Dr. Kaltreider was a U. S. Public Health Service Postdoctoral Fellow (HL-05705).

\section{REFERENCES}

1. Green, G. M. 1968. Pulmonary clearance of infectious agents. Annu. Rev. Med. 19: 315 .

2. Green, G. M. 1970. J. Burns Amberson lecture-In defense of the lung. Am. Rev. Respir. Dis. 102: 691.

3. Mackaness, G. B. 1971. J. Burns Amberson lecture: the induction and expression of cell-mediated hypersensitivity in the lung. Am. Rev. Respir. Dis. 104: 813.

4. McCombs, R. P. 1972. Diseases due to immunologic reactions in the lungs. N. Engl. J. Med. 286: 1186, 1245.

5. Pearsall, N. N., and R. S. Weiser. 1970. The Macrophage. Lea \& Febiger, Philadelphia.

6. Henney, C. S., and R. H. Waldman. 1970. Cell-mediated immunity shown by lymphocytes from the respiratory tract. Science (Wash. D. C.). $169: 696$.

7. Waldman, R. H., and C. S. Henney. 1971. Cell-mediated immunity and antibody responses in the respiratory tract after local and systemic immunization. J. Exp. Med. $134: 482$.

8. Waldman, R. H., C. S. Spencer, and J. E. Johnson, III. 1972. Respiratory and systemic cellular and humoral immune responses to influenza virus vaccine administered parenterally or by nose drops. Cell. Immunol. 3: 294.

9. Myrvik, Q. N., E. S. Leake, and B. Fariss. 1961. Studies on pulmonary alveolar macrophages from the normal rabbit: a technique to procure them in a high state of purity. J. Immunol. 86: 128.

10. Cohen, A. B., and M. J. Cline. 1971. The human alveolar macrophage: isolation, cultivation in vitro, and studies of morphologic and functional characteristics. J. Clin. Invest. 50: 1390.

11. Holub, M., and R. E. Hauser. 1969. Lung alveolar histiocytes engaged in antibody production. Immunology. $17: 207$.

12. Tomasi, T. B., Jr., E. M. Tan, A. Solomon, and R. A. Prendergast. 1965. Characteristics of an immune system common to certain external secretions. J. Exp. Med. $121: 101$.

13. Finley, T. N., E. W. Swenson, W. S. Curran, G. L. Huber, and A. J. Ladman. 1967. Bronchopulmonary lavage in normal subjects and patients with obstructive lung disease. Ann. Intern. Med. 66: 651.

14. Salmon, S. E., G. Mackey, and H. H. Fudenberg. 1969. "Sandwich" solid phase radioimmunoassay for the quantitative determination of human immunoglobulins. J. Immunol. 103 : 129.

15. Salmon, S. E., and B. A. Smith. 1970. Sandwich solid phase radioimmunoassays for the characterization of human immunoglobulins synthesized in vitro. J. Immunol. 104 : 665.

16. Leikola, J., H. H. Fudenberg, G. N. Vyas, and H. A. Perkins. 1971. Isoantibodies to human IgM: serologic and immunochemical investigations. J. Immunol. 106: 1147.

17. Tomasi, T. B., Jr. 1972. Secretory immunoglobulins. N. Engl. J. Med. 287: 500 .

18. Chanock, R. M. 1971. Local antibody and resistance to acute viral respiratory tract disease. In The Secretory Immunologic System. D. H. Dayton, Jr., P. A. Small, Jr., R. M. Chanock, H. E. Kaufman, and T. B. Tomasi, Jr., editors. U. S. Government Printing Office, Washington, D. C. 83.

19. Fernald, G. W., W. A. Clyde, Jr., and J. Bienenstock. 1972. Immunoglobulin-containing cells in lungs of hamsters infected with Mycoplasma pneumoniae. J. Immunol. 108: 1400 .

20. von Hayek, H. 1960. The Human Lung. Hafner Publishing Co., Inc., New York. 298.

21. Gowans, J. L., and E. J. Knight. 1964. The route of recirculation of lymphocytes in the rat. Proc. R. Soc. Lond. B. Biol. Sci. 159 : 257. 